\title{
RESULTS OF THE F/H EFFLUENT TREATMENT FACILITY BIOLOGICAL MONITORING PROGRAM, JULY 1987-JULY 1991 (U)
}

by W.L. Specht

Westinghouse Savannah River Company

Savannah River Site

Aiken, South Carolina 29808

WSRC-RP-92-923

DE93 001893

This paper was prepared in connection with work done under Contract No. DE-AC09-89SR18035 with the U. S. Department of Energy. By acceptance of this paper, the publisher and/or recipient acknowledges the U.S. Government's right to retain a nonexculisve, royalty-free license in and to any copyright covering this paper, along with the right to reproduce and to authorize others to reproduce all or part of the copyrighted paper.

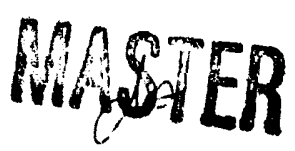




\section{DISCLAIMER}

This report was prepared as an account of work sponsored by an agency of the United States Government. Neither the United States Government nor any agency thereof, nor any of their employees, makes any warranty, express or implied, or assumes any legal liability or responsibility for the accuracy, completeness, or usefulness of any information, apparatus, product, or process disclosed, or represents that its use would not infringe privately owned rights. Reference herein to any specific commercial product, process, or service by trade name, trademark, manufacturer, or otherwise does not necessarily constitute or imply its endorsement, recommendation, or favoring by the United States Government or any agency thereof. The views and opinions of authors expressed herein do not necessarily state or reflect those of the United States Government or any agency thereof.

This report has been reproduced directly from the best available copy.

Available to DOE and DOE contractors from the Office of Scientific and Technical Information, P.O. Box 62, Oak Ridge, TN 37831; prices available from (615) 576-8401, FTS 626-8401.

Available to the public from the National Technical Information Service, U.S. Department of Commerce, 5285 Fort Royal Rd., Springfield, VA 22161. 


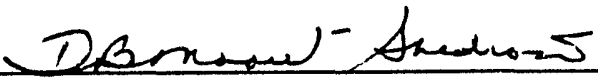

WSRC-RP-92-923

D.B. Moore-Shedrow

Authorized Derivative Classifier

RESULTS OF THE F/H EFFLUENT TREATMENT FACILITY BIOLOGICAL

MONITORING PROGRAM, JULY 1987 - JULY 1991 (U)

Approved by: $\frac{\text { Dron }}{\begin{array}{l}\text { D.B. Moore-Shedrow, Manager } \\ \text { Environmental Sciences Section }\end{array}}$

WINONA L. SPECHT

Publication Date: July 1992

WESTINGHOUSE SAVANNAH RIVER COMPANY

SAVANNAH RIVER SITE

AIKEN, SC 29808

Prepared for the U.S. Department of Energy under Contract No. DE-AC09-89-SR18035 


\section{INTRODUCTION}

As required by the South Carolina Department of Health and Environmental Control (SCDHEC) under NPDES Permit SC0000175, biological monitoring was conducted in Upper Three Runs creek to determine if discharges from the $\mathrm{F} / \mathrm{H}$ Effluent Treatment Facility have adversely impacted the biotic community of the receiving stream. Data included in this summary report encompass July 1987 through July 1991.

The F/H ETF was designed to treat wastewater at the rate of $235 \mathrm{gpm}$. Due to a reduction in process operations in $\mathrm{F}$ and $\mathrm{H}$ Areas, the F/H ETF has never operated at more than about $25 \%$ of design capacity and it is not anticipated that the F/H ETF will operate at more than $25 \%$ of design capacity in the foreseeable future.

As originally designed, the F/H ETF was not expected to remove all of the mercury from the wastewater; therefore, SCDHEC specified that studies be conducted to determine if mercury was bioaccumulating in aquatic biota. Subsequent to approval of the biological monitoring program, an ion exchange column was added to the F/H ETF specifically to remove mercury, which eliminated mercury from the F/H ETF effluent.

\section{DESCRIPTION OF THE MONITORING PROGRAM}

In order to collect preoperational baseline data, the biological monitoring program was initiated in July 1987, approximately 15 months prior to the start-up of the F/H ETF on October 31, 1988. Five sampling stations were selected, with one located upstream from the F/H ETF outfall, one in the mixing zone, and three stations located downstream from the mixing zone,

From July 1987 until February 1990, macroinvertebrates were sampled quarterly at each sampling station using Hester-Dendy multiplate samplers (five replicates per station). In addition, macroinvertebrates were collected from natural substrates at each station semiannually in order to collect taxa that are generally not found on artificial substrate samplers.

Toxicity tests (Ceriodaphnia dubia 7-day reproductive impairment) were conducted on the F/H ETF effluent on a quarterly basis, and NOEC's and LOEC's were determined.

Because it was originally anticipated that the F/H ETF effluent might contain measurable concentrations of mercury, hydropsychid caddisflies were sampled for mercury bioaccumulation. 
In addition, water samples were collected monthly at each station and analyzed for 31 parameters (Table 1). Water samples were also collected weekly for NPDES compliance and the results were submitted to SCDHEC in the monthly Discharge Monitoring Reports. The results of the NPDES sampling are not discussed in this summary report, since the NPDES sampling is not part of the biological monitoring program.

Beginning in March 1990, with concurrence from SCDHEC (letter from C.C. Montgomery to S.R. Wright, January 2, 1990), the sampling program was reduced from five stations to three, with one station located upstream from the F/H ETF outfall (station 1 ), one station located in the mixing zone (Station 2), and one station located approximately $3 \mathrm{~km}$ downstream from the outfall (Station 5; Figure 1). In addition, the frequency of water sampling was reduced from monthly to quarterly, and mercury bioaccumulation studies were conducted on the dusky shiner instead of a caddisfly.

\section{RESULTS}

\section{water Chemistry}

The water chemistry of Upper Three Runs creek is typical of many coastal plain blackwater streams. The water is very soft (approximately $10 \mathrm{mg} / \mathrm{l}$ hardness as $\mathrm{CaCO}_{3}$ ), and poorly buffered (alkalinity $<3 \mathrm{mg} / \mathrm{l}$ ). The addition of the $F / H$ ETF effluent to Upper Three Runs Creek has resulted isl very slight increases in specific conductance, alkalinity, sodium, and nitrate in the stream. Specific conductance in Upper Three Runs has increased by approximately 2 umhos/cm, alkalinity has increased by about $0.3 \mathrm{mg} / 1$, sodium has increased by about 0.3 $\mathrm{mg} / \mathrm{l}$ and nitrate-nitrogen has increased by about $0.06 \mathrm{mg} / \mathrm{l}$. None of the increases are substantial enough to result in any degradation of the stream ecosystem. None of the metals known to be present in the influent of the ETF were found to be present in the effluent at concentrations above those of the receiving stream, and based on water chemistry, no impact to the receiving stream would be expected from the F/H ETF effluent.

\section{Macroinvertebrate community}

The macroinvertebrate data indicate that Upper Three Runs Creek supports very similar macroinvertebrate communities upstream and downstream from the F/H ETF outfall. The macroinvertebrate community is diverse and productive, and there is no evidence that the F/H ETF has adversely affected macroinvertebrates in the stream. Some temporal changes were observed in the macroinvertebrate community over the course of four years, but the changes cannot be attributed to the $F / H$ ETF, since similar changes were observed upstream and downstream from the discharge. 


\section{Toxicity Tests}

Under average and 7Q10 stream discharge conditions, Upper Three Runs Creek dilutes the F/H ETF effluent by factors of $1: 370$ ( $0.27 \%$ effluent) and $1: 225$ ( $0.44 \%$ effluent), respectively. The results of the 7-day ceriodaphnia dubia survival and reproduction toxicity tests that were conducted quarterly all indicate that no toxicity would be expected after the effluent is mixed with the receiving stream. The NOEC was most often $30 \%$ effluent, although on one occasion, an NOEC as low as $1 \%$ effluent was reported.

In general, the toxicity of the effluent has decreased over time. During the last 18 months of sampling, the NOEC was $30 \%$ effluent in 5 of the 6 tests and $3 \%$ effluent for the remaining test.

\section{Mercury Bioaccumulation}

The results of the mercury bioaccumulation studies conducted on hydropsychid caddisflies (Enwright, 1988b) and dusky shiners (Newman, 1992) prior to start-up of the F/H ETF indicate that there was no difference in tissue concentrations of test organisms collected upstream and downstream from the site of the ETF outfall. Mercury analyses conducted on the dusky shiner subsequent to the start-up of the F/H ETF (Newman, 1992) indicate some seasonal differences in mercury concentrations, but no evidence of increased mercury bioaccumulation in fish inhabiting Upper Three Runs Creek downstream from the F/H ETF outfall.

\section{CONCLUSIONS}

The results of the biological monitoring program indicate that at the present rate of discharge, the F/H ETF effluent has not adversely affected the receiving stream with respect to any of the parameters that were measured. The effluent is not toxic at the in-stream waste concentration and there is no evidence of mercury bioaccumulation. 
REFERENCES/SUPPORTING DOCUMENTS

Chem-Nuclear Laboratory Services, Inc. 1990a. F/H Area ETF Effluent (H-016 Outfall) Ceriodaphnia Survival/Reproduction Test, June 26, 1990. Prepared by Chem-Nuclear Laboratory Services, Inc. for Westinghouse Savannah River Company, Aiken, SC. WSRC-TR-90-597.

Chem-Nuclear Laboratory Services, Inc. 1990b. F/H Area ETF Effluent (H-016 Outfali) Ceriodaphnia Survival/Reproduction Test, September 18, 1990. Prepared by Chem-Nuclear Laboratory Services, Inc. for Westinghouse Savannah River Company, Aiken, SC. WSRC-TR-90-598.

Chem-Nuclear Laboratory Services, Inc. 1990C. F/H Area ETF Effluent (H-016 outfali) Ceriodaphnia Survival/Reproduction Test, December 12, 1990. Prepared by Chem-Nuclear Laboratory Services, Inc. for Westinghouse Savannah River Company, Aiken, SC. WSRC-TR-91-474-1.

Chem-Nuclear Laboratory Services, Inc. 1991a. F/H Area ETF Effluent (H-016 outfali) Ceriodaphnia Survival/Reproduction Test, March 21, 1991. Prepared by Chem-Nuclear Laboratory Services, Inc. for Westinghouse Savannah River Company, Aiken, SC. WSRC-TR-91-474-2.

Chem-Nuclear Laboratory Services, Inc. 1991b. F/H Area ETF Effluent (H-016 outfall) Ceriodaphnia Survival/Reproduction Test, June 27, 1991. Prepared by Chem-Nuclear Laboratory Services, Inc. for Westinghouse Savannah River Company, Aiken, SC. WSRC-TR-91-474-3.

Chem-Nuclear Laboratory Services, Inc. 1991c. Biological Monitoring of Upper Three Runs Creek, Savannah River Site, Aiken County, South Carolina, March 1990 - July 1991. Prepared by Chem-Nuclear Laboratory Services, Inc. for Westinghouse Savannah River Company, Aiken, SC. WSRC-RP-911213 .

Enwright Laboratories, Inc. 1988a. Biological Monitoring of Upper Three Runs Creek, Macroinvertebrate Assessment Prior to Release of F/H ETF Effluent Discharge, July 1987-October 1988 . Prepared by Enwright Laboratories, Inc., for E.I. du Pont de Nemours and Company, Aiken, SC. WSRC-OS-89-89.

Enwright Laboratories, Inc. 1988b. Mercury Bioaccumulation by Hydropsychid Caddisflies in Upper Three Runs Creek Prior to Release of F/H Area ETF Effluent Discharge, April 1988September 1988. Prepared by Enwright Laboratories, Inc., for E.I. du Pont de Nemours and Company, Aiken, SC. WSRC-OS-8990 . 
Enwright Laboratories, Inc. 1989a. Biological Monitoring of Upper Three Runs Creek, Savannah River Site, Aiken County, South Carolina. Macroinvertebrate stream Assessments during the First Six Months of Release of F/H ETF Effluent Discharge, October 1988 - April 1989. Prepared by Enwright Laboratories, Inc., for E.I. du Pont de Nemours and Company, Aiken, SC. WSRC-OS-89-91.

Enwright Laboratories, Inc. 1989b. 7-day Chronic Ceriodaphnia Toxicity Test, January 13, 1989. Prepared by Enwright Laboratories, Inc., for E.I. du Pont de Nemours and Company, Aiken, SC. WSRC-OS-89-92.

Enwright Laboratories, Inc. 1989c. Ceriodaphnia Survival/Reproduction Test, February 16, 1989. Prepared by Enwright Laboratories, Inc., for E.I. du Pont de Nemours and Company, Aiken, SC. WSRC-OS-89-93.

Enwright Laboratories, Inc. 1989d. Ceriodaphnia Survival/Reproduction Test, June 17, 1989. Prepared by Enwright Laboratories, Inc., for Westinghouse Savannah River Company, Aiken, SC. WSRC-OS-89-94.

Enwright Laboratories, Inc. 1989e. F/H Area ETF Effluent (H016 outfall) Ceriodaphnia Survival/Reproduction Test, September 21, 1989. Prepared by Enwright Laboratories for Westinghouse Savannah River Company, Aiken, SC. WSRC-OS-8994-2.

Enwright Laboratories, Inc. 1990a. Biological Monitoring of Upper Three Runs Creek, Savannah River Plant, Aiken County, south Carolina. Final Report on Macroinvertebrate stream Assessments for F/H Area ETF Effluent Discharge, July 1987 February 1990. Prepared by Enwright Laboratories for Westinghouse Savannah River Company, Aiken, SC. WSRC-RP-91-1046.

Enwright Laboratories. 1990b. F/H Area ETF Effluent (H-016 Outfall) Ceriodaphnia Survival/Reproduction Test, March 27, 1990. Prepared by Enwright Laboratories for Westinghouse Savannah River Company, Aiken, SC. WSRC-TR-90-596.

Montgomery, C.C. 1990. Letter From C.C. Montgomery, Environmental Quality Manager, Water Quality Assessment and Enforcement Division, SCDHEC, to S.R. Wright, Director of Environmental Division, U.S. DOE, Savannah River operations, January 2,1990 .

Newman, M.C. 1992. Letter report and data transmitted to W.L. Specht, WSRC, JulY $30,1992$. 
DATE

FILMED

$12 / 17 / 92$ 
